\title{
Exploitability of cultivated and wild cardoon as long-term, low-input energy crops
}

\author{
Rosario Paolo Mauro, Orazio Sortino, Gaetano Roberto Pesce, Michele Agnello, \\ Sara Lombardo, Gaetano Pandino, Giovanni Mauromicale \\ Dipartimento di Agricoltura, Alimentazione e Ambiente, Università di Catania, Italy
}

\begin{abstract}
The potential ability in terms of biomass, achenes, oil and energy yield of two Cynara cardunculus L. genotypes (one cultivated cardoon and one wild cardoon) was evaluated along a 7-year experiment. It was carried out in a marginal farmland of Southern Italy, with low soil fertility and minimal external inputs. Under these conditions, they reached an annual harvestable biomass ranging from 0.74 (wild cardoon) to $1.46 \mathrm{~kg} \mathrm{~m}^{-2}$ (cultivated cardoon) and an energy yield ranging from 13.8 to $27.5 \mathrm{~kJ} \mathrm{~m}^{-2}$. The lower heating value of biomass (including achenes) was on average $18.2 \mathrm{~kJ} \mathrm{~kg}^{-1}$, while the oil yield from ach-

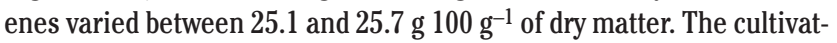
ed cardoon was able to produce high yields until the fifth season and therefore is prone for medium long-time cropping systems. Conversely, wild cardoon showed a most stable yield pattern and plant survival over seasons, suggesting its particular suitability for perennial cropping systems in Mediterranean marginal areas.
\end{abstract}

\section{Introduction}

The increasing spread of bioenergy crops offers significant opportunities for Europe to reduce greenhouse gas emission and ensure its energy supply. However, because of the low per unit-value, an adequate

Correspondence: Rosario Paolo Mauro, Dipartimento di Agricoltura, Alimentazione e Ambiente (Di3A), Università di Catania, via Valdisavoia 5, I-95123 Catania, Italy.

Tel.: +39.095.234.415 - Fax: +39.095.234.449.

E-mail: rosario.mauro@unict.it

Key words: achenes, bioenergy, biomass, cardoon.

Conference presentation: SIA XLIII Congress, Pisa, 2014.

Received for publication: 29 November 2014.

Revision received: 11 January 2015.

Accepted for publication: 12 January 2015.

(C) Copyright R.P. Mauro et al., 2015

Licensee PAGEPress, Italy

Italian Journal of Agronomy 2015; 10:638

doi:10.4081/ija.2015.638

This article is distributed under the terms of the Creative Commons Attribution Noncommercial License (by-nc 3.0) which permits any noncommercial use, distribution, and reproduction in any medium, provided the original author(s) and source are credited. production under minimal external inputs is desirable for growers to profit from producing biomass (Knoll et al., 2012). Cynara cardunculus L. is native to the Mediterranean Basin, and includes the three taxa globe artichoke (var. scolymus L.), cultivated cardoon (var. altilis DC.) and their common ancestor wild cardoon (var. sylvestris Lam.) (Mauro et al., 2007; Portis et al., 2014). Both cultivated and wild cardoon have been recognised as promising energy crops for rainfed farmlands in Mediterranean climates. In particular, they produce lignocellulosic biomass and oil seeds (for solid biofuel and biodiesel) (Portis et al., 2012; Acquadro et al., 2013). The interest for these crops comes from their high biomass and energy yields under low external management energy supplies (Ierna et al., 2012). This peculiarity is supported by the excellent adaptation of Cynara spp. to the Mediterranean climate, owing to the positive balance between the phases of the growth and development cycle with Mediterranean climatic trends, the capacity of photosynthesizing during winter time, as well as the capacity of nutrient uptake from deep soil layers (Fernández et al., 2006). The objective of our study was: i) to evaluate the long-term seasonal dynamic of biomass, achenes, oil and energy yield in cultivated and wild cardoon under minimal input; ii) to identify possible germplasm for breeding aimed at constituting specific genotypes for bioenergy purposes.

\section{Materials and methods}

\section{Site and soil}

A field experiment was conducted in Sicily ( $36^{\circ} 47^{\prime} \mathrm{N}, 14^{\circ} 54^{\prime} \mathrm{E}, 42$ $\mathrm{m}$ asl), over seven years (from 2005-2006 to 2011-2012, hereafter referred as $S_{1}-S_{7}$ ) in a moderately deep calcic brown soil with sandy loam texture. The local climate is semi-arid-Mediterranean, with mild, wet winters and hot, dry summers. The mean seasonal rainfall over the period 1929-1998 was $481 \mathrm{~mm}$, mostly concentrated from October to February. From March to August, temperature increases rapidly, with maximum temperatures ranging from 15.8 to $32.5^{\circ} \mathrm{C}$.

\section{Experimental design and crop management}

The experiment was arranged as a randomized block design with four replications, $44 \mathrm{~m}$ each. Two genotypes were studied: a cultivated cardoon Bianco Avorio and a wild cardoon landrace collected from native stands in South-Eastern Sicily ( $36^{\circ} 55^{\prime}$ N, $14^{\circ} 43^{\prime}$ E, $502 \mathrm{~m}$ asl). Four-week-old seedlings were transplanted on November 5, 2005 (2 plants $\mathrm{m}^{-2}$ ), on a soil previously ploughed, harrowed and fertilised with $60 \mathrm{~kg} \mathrm{ha}^{-1} \mathrm{~N}$ (as urea), $100 \mathrm{~kg} \mathrm{ha}^{-1} \mathrm{P}_{2} \mathrm{O}_{5}$ (as triple superphosphate) and $80 \mathrm{~kg} \mathrm{ha}^{-1} \mathrm{~K}_{2} \mathrm{O}$ (as potassium sulphate). In late-February 2006, 60 $\mathrm{kg} \mathrm{ha}^{-1} \mathrm{~N}$ (as urea) were applied. After transplanting an irrigation (30 $\mathrm{m}^{3} \mathrm{ha}^{-1}$ ) was adopted. In the following years no external inputs were supplied. Crop regrowth from $\mathrm{S}_{2}$ onward was naturally allowed by rains. 


\section{Data collection and analysis}

In each year, on late-August stand density was assessed, and the above-ground biomass was harvested by cutting the plants at ground level from the centre of each plot; plants' subsamples were reweighed after desiccation at $105^{\circ} \mathrm{C}$, to determine the dry biomass yield. Achenes were separated from the heads through a specific mini-thrasher. In each season the collected biomass was milled to $3.0 \mathrm{~mm}$ (MF10 IKA mill) to determine the lower heating value (C200-System-IKA calorimeter), while achenes oil yield was determined by standard procedure according to the UNI EN ISO 659:2009 norm. Collected data were submitted to analysis of variance, while means comparisons were performed through Fisher's least significant difference test.

\section{Results and discussion}

\section{Stand density}

On the whole $S_{1}-S_{7}$ period, a higher stand density was recorded in wild cardoon (1.97 plants $\left.\mathrm{m}^{-2}\right)$ than in cultivated cardoon $\left(1.86 \mathrm{~m}^{-2}\right)$ (Table 1). The former entry showed little variation over $\mathrm{S}_{1}-\mathrm{S}_{7}$ (from 1.99 to 1.94 plants $\mathrm{m}^{-2}$ ), while cultivated cardoon had a linear decrease over $\mathrm{S}_{1}-\mathrm{S}_{5}$ (from 1.98 to 1.83 plants $\mathrm{m}^{-2}$ ) and then a sharper decrease over $\mathrm{S}_{5}-\mathrm{S}_{7}$ (up to 1.71 plants $\mathrm{m}^{-2}$ ) (Table 1). Problems related to cultivated cardoon survival in long-term trials were pointed out as one of the limiting factors for its yield potentiality in the Mediterranean area (Gherbin et al., 2001). In our experiment, despite its lower yield, wild cardoon showed a greater ability to lend itself to long-term and zeroinput cultivation period, which well reproduce its natural cropping conditions in the Mediterranean area (Ierna et al., 2012). From a breeding point of view, this aspect should be taken into account, in order to increase the crop duration over time and improve its agronomical performances in Mediterranean marginal farmland.

\section{Above-ground dry biomass yield}

Over the period $S_{1}-S_{7}$, the biomass yield of cultivated cardoon was about 2 times higher than that of wild cardoon [ $1.46 \mathrm{vs} 0.74 \mathrm{~kg}$ dry matter (DM) $\mathrm{m}^{-2}$ year-1 $^{-1}$ (Table 1), with the pattern of biomass yield across seasons significantly differing between genotypes. The above-ground dry biomass yield of cultivated cardoon significantly increased from $\mathrm{S}_{1}$ to $S_{5}$ (from 0.97 to $2.20 \mathrm{~kg} \mathrm{DM} \mathrm{m}^{-2}$ ), then it dropped down to $1.06 \mathrm{~kg} \mathrm{DM}$ $\mathrm{m}^{-2}$ at $\mathrm{S}_{7}$ (Table 1). By contrast, wild cardoon biomass yield increased from $S_{1}\left(0.55 \mathrm{~kg} \mathrm{DM} \mathrm{m}^{-2}\right)$ to $\mathrm{S}_{5}\left(0.88 \mathrm{~kg} \mathrm{DM} \mathrm{m}^{-2}\right)$, afterwards it remained somewhat stable until $S_{7}\left(0.81 \mathrm{~kg} \mathrm{DM} \mathrm{m}^{-2}\right)$ (Table 1). This was a pivotal difference among the tested genotypes, since wild cardoon, though less yielding showed a more conservative profile in biomass yield over seasons. This reflects its stable percentage of plant survival over time and better adaptability to the xerothermic conditions of Mediterranean area. The latter trait might be taken into account in the context of possible breeding programs for this crop; indeed, a more stable biomass production over time could have in the near future a pivotal role for the construction of more robust and reliable feedstock production for the biomass supply chains.

\section{Achenes yield and oil content}

Cultivated cardoon yielded $139 \%$ more achenes than wild cardoon (55 vs $24 \mathrm{~g} \mathrm{~m}^{-2}$ ) (Table 1), but their yield trend across seasons was substantially different. In cultivated cardoon, the achenes yield was almost constant from $S_{1}$ to $S_{6}$ (on average, $60 \mathrm{~g} \mathrm{~m}^{-2}$ ), while it decreased in $S_{7}$ (32 $\mathrm{g} \mathrm{m}^{-2}$ ); the achenes yield of wild cardoon, on the contrary, increased by $24 \%$ at $\mathrm{S}_{6}-\mathrm{S}_{7}$ as compared to $\mathrm{S}_{1}-\mathrm{S}_{2}$ (Table 1). Achenes oil content did not significantly differ between genotypes, but their pattern significantly differed among seasons (Table 2). Indeed, in cultivated cardoon achenes oil yield tended to increase passing from $S_{1}(25.0 \mathrm{~g}$

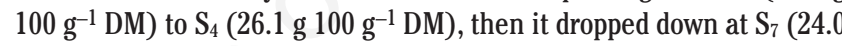
g $100 \mathrm{~g}^{-1} \mathrm{DM}$ ) (Table 2), showing overall $27 \%$ coefficient of variation over the $S_{1}-S_{7}$ period. In contrast, wild cardoon showed a somewhat sta-

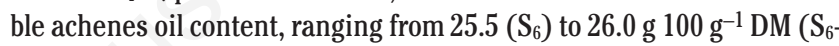
$\mathrm{S}_{7}$ ) (Table 2). Seed set in C. cardunculus is a delicate phase, whose success can be heavily influenced by both the climatic conditions during flowering and nutritional status of the plant. Our experiment demonstrates that, when compared to cultivated cardoon, wild cardoon has been slightly affected by these factors. This suggests a better photosynthetic efficiency during stressful climatic conditions occurring at the achenes filling stage (early summer), and under poor fertility soil conditions. All these traits should be taken into account in the light of a specific breeding program for bioenergy purposes, in order to constitute genotypes characterized by both adequate yield levels and adaptability to stressful conditions and marginal agroecosystems, and to maximize the profit from both biomass and biodiesel chains.

\section{Lower heating value and energy yield}

Lower heating value (LHV) of biomass including achenes was very similar in both Cynara accessions, but they showed a different pattern

Table 1. Plant survival, biomass and achenes yield in Cynara cardunculus L. as affected by genotype $\times$ season interaction.

\begin{tabular}{|c|c|c|c|c|c|c|}
\hline \multirow[t]{2}{*}{ Season of cultivation } & \multicolumn{2}{|c|}{$\begin{array}{l}\text { Stand density } \\
\left.\text { (plant } \mathrm{m}^{-2}\right)\end{array}$} & \multicolumn{2}{|c|}{$\begin{array}{l}\text { Above-ground biomass yield } \\
\text { (kg m-2 DM) }\end{array}$} & \multicolumn{2}{|c|}{$\begin{array}{l}\text { Achenes yield } \\
\qquad\left(\mathrm{g} \mathrm{m}^{-2}\right)\end{array}$} \\
\hline & $\begin{array}{l}\text { Cultivated } \\
\text { cardoon }\end{array}$ & $\begin{array}{l}\text { Wild } \\
\text { cardoon }\end{array}$ & $\begin{array}{l}\text { Cultivated } \\
\text { cardoon }\end{array}$ & $\begin{array}{l}\text { Wild } \\
\text { cardoon }\end{array}$ & $\begin{array}{l}\text { Cultivated } \\
\text { cardoon }\end{array}$ & $\begin{array}{l}\text { Wild } \\
\text { cardoon }\end{array}$ \\
\hline$S_{1}$ & 1.98 & 1.99 & 0.97 & 0.55 & 59 & 21 \\
\hline $\mathrm{S}_{2}$ & 1.96 & 1.99 & 1.59 & 0.64 & 65 & 20 \\
\hline $\mathrm{S}_{3}$ & 1.90 & 1.99 & 1.55 & 0.67 & 52 & 25 \\
\hline $\mathrm{S}_{4}$ & 1.86 & 1.96 & 1.63 & 0.81 & 54 & 23 \\
\hline $\mathrm{S}_{5}$ & 1.83 & 1.95 & 2.20 & 0.88 & 64 & 26 \\
\hline $\mathrm{S}_{6}$ & 1.78 & 1.94 & 1.22 & 0.83 & 61 & 25 \\
\hline $\mathrm{S}_{7}$ & 1.71 & 1.94 & 1.06 & 0.81 & 32 & 26 \\
\hline Mean & $1.86^{\mathrm{b}}$ & $1.97^{\mathrm{a}}$ & $1.46^{\mathrm{a}}$ & $0.74^{b}$ & $55^{\mathrm{a}}$ & $24^{b}$ \\
\hline $\mathrm{LSD}_{\text {interaction }}$ & \multicolumn{2}{|c|}{0.05} & \multicolumn{2}{|c|}{0.23} & \multicolumn{2}{|c|}{7} \\
\hline
\end{tabular}

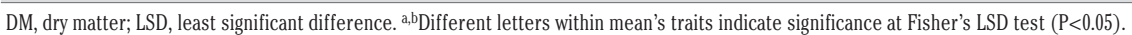


Table 2. Achenes oil yield, lower heating value (biomass plus achenes) and energy yield in Cynara cardunculus $\mathrm{L}$. as affected by genotype $\times$ season interaction.

\begin{tabular}{|c|c|c|c|c|c|c|}
\hline \multirow[t]{2}{*}{ Season of cultivation } & \multicolumn{2}{|c|}{$\begin{array}{l}\text { Achenes oil content } \\
\quad\left(\mathrm{g} 100 \mathrm{~g}^{-1} \mathrm{DM}\right)\end{array}$} & \multicolumn{2}{|c|}{$\begin{array}{c}\text { Lower heating value } \\
\text { (biomass plus achenes) } \\
\left(\mathrm{kJ} \mathrm{kg}^{-1}\right)\end{array}$} & \multicolumn{2}{|c|}{$\begin{array}{l}\text { Energy yield } \\
\qquad\left(\mathrm{g} \mathrm{m}^{-2}\right)\end{array}$} \\
\hline & $\begin{array}{l}\text { Cultivated } \\
\text { cardoon }\end{array}$ & $\begin{array}{l}\text { Wild } \\
\text { cardoon }\end{array}$ & $\begin{array}{l}\text { Cultivated } \\
\text { cardoon }\end{array}$ & $\begin{array}{l}\text { Wild } \\
\text { cardoon }\end{array}$ & $\begin{array}{l}\text { Cultivated } \\
\text { cardoon }\end{array}$ & $\begin{array}{l}\text { Wild } \\
\text { cardoon }\end{array}$ \\
\hline S1 & 25.0 & 25.5 & 17.4 & 17.9 & 18.6 & 10.3 \\
\hline S2 & 25.3 & 25.7 & 18.0 & 18.0 & 31.5 & 12.5 \\
\hline S3 & 24.8 & 25.6 & 19.0 & 17.7 & 31.6 & 13.7 \\
\hline S4 & 26.1 & 25.9 & 19.8 & 17.9 & 29.3 & 14.5 \\
\hline S5 & 25.9 & 25.8 & 17.8 & 18.4 & 40.3 & 16.1 \\
\hline S6 & 24.8 & 26.0 & 17.3 & 18.9 & 22.1 & 14.8 \\
\hline S7 & 24.0 & 26.0 & 17.4 & 19.0 & 19.0 & 14.0 \\
\hline Mean & $25.1^{\mathrm{a}}$ & $25.8^{\mathrm{a}}$ & $18.1^{\mathrm{a}}$ & $18.3^{\mathrm{a}}$ & $27.5^{\mathrm{a}}$ & $13.7^{\mathrm{b}}$ \\
\hline$\underline{\mathrm{LSD}_{\text {interaction }}}$ & \multicolumn{2}{|c|}{0.6} & \multicolumn{2}{|c|}{0.4} & \multicolumn{2}{|c|}{4.1} \\
\hline
\end{tabular}

DM, dry matter; LSD, least significant difference. ${ }^{a, b}$ Different letters within mean's traits indicate significance at Fisher's LSD test $(\mathrm{P}<0.05)$.

of variability along the $S_{1}-S_{7}$ period (Table 2$)$. In cultivated cardoon LHV increased from $S_{1}\left(17.4 \mathrm{~kJ} \mathrm{~kg}^{-1} \mathrm{DM}\right)$ to $\mathrm{S}_{4}\left(19.8 \mathrm{~kJ} \mathrm{~kg}^{-1} \mathrm{DM}\right)$, then showed a sharp decrease from $S_{5}$ onward (up to $17.4 \mathrm{~kJ} \mathrm{~kg}^{-1} \mathrm{DM}$ ). On the contrary wild cardoon reported a more stable LHV along the whole experimental period, which ranged from $17.7\left(\mathrm{~S}_{3}\right)$ to $19.0 \mathrm{~kJ} \mathrm{~kg}^{-1} \mathrm{DM}$ $\left(\mathrm{S}_{7}\right)$ (Table 2). As regards the energy yield, cultivated cardoon doubled wild cardoon over the whole $S_{1}-S_{7}$ cropping period $\left(27.5\right.$ vs $13.8 \mathrm{~kJ} \mathrm{ha}^{-1}$ year $^{-1}$ ); however, when comparing their energy yield pattern, both genotypes showed distinct trends across years (Table 2). Indeed, in cultivated cardoon the energy yield significantly increased from $18.6\left(\mathrm{~S}_{1}\right)$ to $40.3 \mathrm{~kJ} \mathrm{~m}^{-2}\left(\mathrm{~S}_{5}\right)$, then drastically decreased from $\mathrm{S}_{6}$ onward $(20.6 \mathrm{~kJ}$ $\mathrm{m}^{-2}$ ) (Table 2). Differently, in wild cardoon the energy yield continuously increased over the $S_{1}-S_{5}$ period (from 10.3 to $16.1 \mathrm{~kJ} \mathrm{~m}^{-2}$ ) and thereafter showing no significant variations (Table 2). Our experiment demonstrates the high ability of cultivated cardoon to valorise both the Mediterranean marginal lands and low inputs agronomical practices. This has important implications within the concerns about the antagonistic land use between food and energy crops, since high yield levels in marginal fertility farmlands could maximize the benefits from the large-scale implementation of this crop, minimizing, also, the environmental costs of producing bioenergy. However, it might be noted that such convenient energy yield in low fertility conditions was achieved by a genotype not specifically released for energy production, so we can argue that specific breeding programs could significantly improve the agronomic performances of the crop.

\section{Conclusions}

The data presented here indicate $C$. cardunculus L. (both cultivated and wild cardoon) as a very promising renewable energy crop in marginal soil managed under zero/minimal inputs. In this context, the long-period cropping of $C$. cardunculus $\mathrm{L}$. reached 1.46 (cultivated cardoon) and 0.74 (wild cardoon) $\mathrm{kg} \mathrm{m}^{-2}$ of dry biomass per year, of which 55 and $24 \mathrm{~g} \mathrm{~m}^{-2}$ of achenes, corresponding to an energy yield of 27.5 and $13.7 \mathrm{~kJ} \mathrm{~m}^{-2}$. The two botanical varieties displayed a different production pattern across seasons. Cultivated cardoon, due to its yield timing, appears to be more suitable for medium-period cropping systems.
Wild cardoon, on the contrary, revealed a continuous increasing over the seasons 1-5, followed by no significant yield variations from $\mathrm{S}_{5}$ onward. The conservative profile in biomass yield and in plant survival with crop ageing of wild cardoon together with its pests, pathogens and weeds resistance/tolerance should represent a good and additional opportunity for marginal Mediterranean areas to develop a new model of perennial bioenergy crops.

\section{References}

Acquadro A, Portis E, Scaglione D, Mauro RP, Campion B, Falavigna A, Zaccardelli R, Ronga D, Mauromicale G, Lanteri S, 2013. CYNERGIA project: exploitability of Cynara cardunculus L. as energy crop. Acta Hort. 983:109-15.

Fernández J, Curt MD, Aguado PL, 2006. Industrial applications of Cynara cardunculus L. for energy and other uses. Ind. Crop. Prod. 24:222-29.

Gherbin P, Monteleone M, Tarantino E, 2001. Five year evaluation on cardoon (Cynara cardunculus L. var. altilis) biomass production in a Mediterranean environment. Ital. J. Agron. 5:11-9.

Ierna A, Mauro RP, Mauromicale G, 2012. Biomass, grain and energy yield in Cynara cardunculus L. as affected by fertilization, genotype and harvest time. Biomass Bioenerg. 36:404-10.

Knoll JE, Anderson WF, Strickland TC, Hubbard RK, Malik R, 2012. Lowinput production of biomass from perennial grasses in the coastal plain of Georgia, USA. Bioenerg. Res. 5:206-14.

Mauro R, Ierna A, Portis E, Lanteri S, Mauromicale G, 2007. Morphological and molecular characterization of autochthonous Sicilian globe artichokes grown in family gardens. Acta Hort. 730:113-21.

Portis E, Mauro RP, Barchi L, Acquadro A, Mauromicale G, Lanteri S, 2014. Mapping yield-associated QTL in globe artichoke. Mol. Breeding 34:615-30.

Portis E, Scaglione D, Acquadro A, Mauromicale G, Mauro R, Knapp SJ, Lanteri S, 2012. Genetic mapping and identification of QTL for earliness in the globe artichoke/cultivated cardoon complex. BMC Res. Notes 5:252-66. 